\title{
Teachers' Attitudes and Opinions about Design and Skill Workshops and Ranking of Workshops by Teachers
}

\author{
Aysegul Bayraktar (Di) 1, Seher Yalcin (D) 1,*
}

${ }^{1}$ Ankara University, Faculty of Education, Ankara, Turkey.

\author{
ARTICLE HISTORY \\ Received: Mar. 19, 2020 \\ Revised: Dec. 09, 2020 \\ Accepted: Jan. 06, 2021 \\ Keywords: \\ Design and skill workshops, \\ Teachers' attitudes, \\ Rankings of workshops \\ based on their importance.
}

\begin{abstract}
In this study, the aim was to both develop a valid and reliable measurement tool for determining teachers' attitudes as well as to determine their opinions towards design and skill workshops (DSW). In addition, the researchers aimed to determine how teachers rank design and skill workshops based on their importance. Since an attempt was made to describe the existing situation at just one point in time, a cross-sectional survey model was used. Teachers working at schools with DSW located in the cities of Ankara and Istanbul, Turkey were chosen as participants. Criterion sampling method, which is a purposeful sampling method was used for determining the sample of this study. A total of 123 teachers working at four primary schools in Ankara as well as 99 teachers working at three secondary schools, one primary school, and two high schools in Istanbul during February 2019 participated to this current study. As a result of interviews with the teachers and members of the General Directorate of Teacher Training in the Turkish Ministry of National Education (MoNE) the scale items were written. As a result of the principal components analysis for attitude scale, a valid and reliable measurement tool with 10 items emerged after removing overlapping items. According to rankings of the various workshops' importance, the teachers were divided into two groups, including those who thought that software and science were more important and those who thought that drama and visual arts were more important.
\end{abstract}

\section{INTRODUCTION}

In 2018, the Ministry of National Education (MoNE) in Turkey planned to establish "DesignSkill Workshops" (DSW) based on the agenda for their "Educational Vision of 2023" (Ministry of National Education, 2018). The purpose of opening these DSW was to provide opportunities for acquiring skills associated with the interests and abilities of students at all levels of education starting from primary school. These workshops were structured to focus on $21^{\text {st }}$ century skills such as science, art, sports, and culture (MoNE, 2018). Workshops provided students with multiple and optional learning opportunities to reveal students' creativity in every field. Thus, through workshop participation, the students can create original works (Öztütüncü, 2016).

CONTACT: Seher Yalcin $\bigotimes$ yalcins@ankara.edu.tr $\equiv$ Ankara University, Faculty of Education, Ankara, Turkey. 
In the second period of 2019, teachers who were planning to be involved in workshops where the pilot applications were being started, were provided training by the authors of this study in collaboration with the MoNE. During these training seminars, it was observed that the teachers were concerned about the use of skill workshops and that there were differences in determining the order of workshops based on their importance. A review of related literature showed that teachers' opinions regarding science, technology, and/or coding are frequently investigated (Bakırc1 \& Kutlu, 2018; Göksoy \& Y1lmaz, 2018; Hsu, Purzer, \& Cardella, 2011). In addition, teachers' opinions regarding drama activities are investigated in Güler and Kandemir (2015). In research by Kurt and Duran (2019), where teachers are asked how they view the establishment of design and skill workshops in the MoNE Educational Vision of 2023, it is observed that teachers reflect on deficiencies in physical infrastructure and their anxieties regarding teaching in these design and skills workshops. In a study by Gündoğan and Can (2020), aimed at determining the opinions of teachers about design-skill workshops, it is found that elementary school teachers have some expectations from other teachers, parents, and school principals regarding design skill workshops. According to these teachers, workshops contribute to students in terms of their development periods, self-perception, choosing a profession, having positive attitudes towards schools, and using their spare time effectively. Factors such as having teachers who are incompetent, increased workload of teachers, parents seeing workshops as requiring extra expenses, and limited physical infrastructure are among the difficulties listed that may be experienced through this process (Gündoğan \& Can, 2020).

As seen in meta-analysis studies (Allen, Witt, \& Wheeless, 2006; Witt, Wheeless, \& Allen, 2004) regarding teacher behaviors in education and teaching, teachers heavily affect student achievement. Teachers' attitudes are important for increasing students' self-development, academic achievement, and creativity skills (Erdoğdu, 2006). In this context, the aim of this current study was to develop an attitude scale to determine the attitudes of teachers towards workshops since teachers' attitudes may affect their behaviors, and in turn, their behaviors can influence students' learning. It is known that one of the most important factors affecting individuals' behavior towards an event or situation is the attitude towards that particular event or situation (Fishbein \& Ajzen, 1975). Attitudes can also make it easier for individuals to adapt to their environment. Teachers' attitudes and behaviors affect students' learning and motivation as well as their academic, social, and emotional development (Sezer, 2018). Therefore, in this study, the aim was to determine the attitudes of teachers towards the DSW opened in pilot schools. To predict teachers' attitudes, it is crucial that their attitudes be measured with a valid and reliable tool (Tavşanc1l, 2010). Since there was no such tool in the literature, the need to develop a valid and reliable measurement tool aimed at understanding teachers' attitudes towards DSW was determined in this current study. In addition, to determine the effects of DSW workshops on all stakeholders, the opinions of teachers regarding the effects of these workshops on students, school principals, and parents were determined through a questionnaire. Finally, another aim was to determine how teachers ranked workshops according to their importance for students' development. The workshops targeted to be opened by the MoNE were: I) Outdoor Sports (football, basketball, tennis, etc.), II) Wood and Metal (wood carving, wire bending, wood design, etc.), III) Garden and Animal Care (agricultural production, planting, maintenance, landscaping, etc.), IV) Language and Critical Thinking, V) Drama (theater, diction, pantomime, etc.), VI) Science, Technology, Engineering and Mathematics, VII) Visual Arts (painting, sculpture, ceramic, etc.), VIII) Music, IX) Indoor Sports (karate, gymnastics, dance, etc.), X) Life Skills (simple repairs, using small appliances, etc.), and XI) Software and Design (robotics and coding, software, design, etc.).

In the literature, while there are studies in which teachers' opinions regarding some workshops are considered, there was no study found that determines teachers' attitudes towards the 11 workshops listed in this current study as well as which workshops are in general found as most 
important by teachers. Therefore, in this study, the aim was to determine the attitudes of teachers about design and skill workshops, which were carried out as pilot studies in several schools in 2019 according to the MoNE (2018) Educational Vision of 2023. Thus, it was hoped that the attitudes of teachers about DSW, which will gradually spread to other schools, would be determined, and if necessary, MoNE would take measures regarding these issues. In addition, it is important to determine the teachers' priorities about the workshops to be opened. Also, it is extremely important that the students who are currently growing up in Turkey, gain 21 st century skills to increase their competitive potential for the overall good of the country. Thus, in this study, another aim was to determine teachers' attitudes and opinions about the importance of these design and skills workshops functioning in pilot schools. In this context, the questions to be answered were as follows:

1. Is the attitudes scale of the teachers towards the design and skill workshops valid and reliable?

2. What are the opinions of the teachers towards the design and skill workshops?

3. What are the teachers' profiles according to the importance order of the workshops to be opened?

\section{METHOD}

In this current study, attempts were made to determine the attitudes of teachers regarding DSW and the order of importance of these workshops at one point in time. Thus, a cross-sectional survey model was utilized in this study (Fraenkel, Wallen, \& Hyun, 2012).

\subsection{Participants}

Criterion sampling method, which is a purposeful sampling method, was used in the scope of this study. The participating teachers were chosen based on their working in schools selected as pilot schools where the DSW were implemented in 2019. Overall, a total of 222 teachers, with 123 teachers working at four primary schools in Ankara, Turkey as well as 99 teachers working at three secondary schools, one primary school, and two high schools in Istanbul, Turkey during February 2019 were chosen as participants. Among the 222 participating teachers, 156 were women $(70.3 \%), 61$ were men $(27.5 \%)$ and $2.2 \%$ did not provide information regarding their sex. The teachers' seniority ranged from one year of teaching to 44 years, and the average years of experience was 17.73 years $(S D=10.97)$. Although teachers from a variety of disciplines including mathematics, science, and language took part in the scope of this study, it was recognized that most of the participating teachers were elementary school teachers $(f=102,45.9 \%)$. While, $6.3 \%(f=14)$ of the participants were mathematics teachers, $5.9 \%(\mathrm{f}=13)$ were Turkish language teachers, $5.4 \%(\mathrm{f}=12)$ were English language teachers, $5 \%(f=11)$ were Science teachers, $5 \%(f=11)$ were Religion teachers, and the remaining $26.5 \%$ taught other subjects.

\subsection{Data Collection Process and Tools}

While preparing the measurement tool, first, what the researchers wanted to measure was clearly determined (DeVellis, 2003). Since the attitudes and opinions of the teachers were what the researchers were seeking to examine, a total of 41 items were prepared, as measures of teachers' attitudes and opinions. Thus, scale and questionnaire items were created based on interviews conducted with the teachers as well as the Teacher Training Directorate working within the Turkish Ministry of National Education. After the item writing stage was completed, in the following third stage, the format of the measurement tool was determined (DeVellis, 2003). While preparing the scale and questionnaire, 41 items were written using a five-point Likert type scale (strongly disagree, disagree, undecided, agree, and strongly agree). Structuring of the rating option of items as either verbal or numerical can differentiate a 
respondent's attitude due to the confounding effect of the meaning attributed to numbers. For example, when each rating is clearly expressed verbally, the reliability coefficient gets higher (Uyumaz \& Çokluk, 2016). Therefore, ratings are better expressed verbally. Subsequently, the items should be reviewed by experts (DeVellis, 2003). As a result, to determine the suitability of items in this study, the opinions of experts were received from one Turkish language instructor and three instructors working at a public university in the Department of Measurement and Evaluation. While 11 items of the scale consisted of teachers' attitudes towards DSW, 30 items in the questionnaire reflected teachers' opinions in terms of the effects of the workshops on students, teachers, parents, and administrators. Thus, the data were collected through the finalized questionnaire and scale items developed by the researchers.

In addition, the prepared questionnaire included the names of 11 workshops that MoNE was planning to open in piloted schools, and the participating teachers were asked to rank the workshops beginning with 1 which in their opinion was the most important for increasing the competitive potential of our country and so forth to 11 , which they consider as the least important.

\subsection{Data Analysis}

Before the analysis, the collected data of this study were analyzed in terms of the required assumptions. Firstly, the data set were examined in terms of missing values, and it was found that no more than five people failed to respond to an item. This was a rate of approximately $2 \%$, which is less than 5\%, thus, the listwise deletion method was utilized (Tabachnick \& Fidell, 2001). Next, the data set was examined in terms of the univariate outlier and multivariate outlier values, and as a result, the outlier values were deleted and a total of 201 teachers' responses remained. Also, the skewness and kurtosis coefficients were examined to meet the normal distribution assumption of the data, and it was observed that they ranged from -3 to +3 . In addition, Bartlett's sphericity test result was found to be less than .05, thus, it was understood that the data came from a multivariate normal distribution (Çokluk, Şekercioğlu \& Büyüköztürk, 2010). Finally, correlations between the items were examined and they were determined to not be above .90 . Therefore, the data were found to provide the necessary assumptions for analysis. Also, six items in the scale (items 1,2, 3, 4, 5 and 6) were coded in reverse.

To determine the construct validity of the attitude scale of the DSW, a principal components analysis (PCA) was conducted. In this study, the reason of using principal components analysis instead of exploratory factor analysis (EFA) was that the observed measurements did not have a quantification appropriate to the theoretical model (Hovardaoğlu, 2000). In addition, the Promax rotation method can be used for investigating the relationship between the components, since it is an economical and quick methodology (Tabachnick \& Fidell, 2001). For the validity of items, the Pearson product-moment correlation coefficient was utilized to calculate the item total test correlation as well as to calculate the relationship between the sub-dimensions. According to Büyüköztürk (2013), a correlation coefficient, as absolute value, between 0.00 and 0.30 indicates low level of correlation while a value between 0.31 and 0.69 is accepted as a medium level of correlation, and a value between 0.70 and 1.00 indicates a high level of correlation. The Cronbach's alpha coefficient was calculated to test reliability of all the scale sub-dimensions, and as Alpar (2010) points out, a Cronbach's alpha internal consistency coefficient between 0.00 and 0.40 indicates the scale is unreliable, when it is between 0.41 and 0.60 the scale reliability is low, between 0.61 and 0.80 the scale is moderately reliable, and between 0.81 and 1.00 the scale is considered highly reliable. In addition, the frequency and percentages were calculated for the survey items. The analyses regarding the validity and reliability of the developed measurement tool as well as the frequencies and percentages of the 
questionnaire items in this current study were conducted with the assistance of the SPSS software program.

As part of the third sub-purpose of the study, data were obtained from the teachers' ranking of different workshops from the most important to the least important. Also, to reveal the profiles of teachers who chose diverse workshops as the most important, a latent class analysis (LCA) was used. According to Vermunt and Magidson (2004), LCA, which began with the use of categorical data analysis, has developed to be applied to data such as continuous and ordinal data. The purpose of LCA is to identify latent variables that explain the relationships between observed data. The in the latent class analysis, all observed variables are the cause of an unobserved latent variable. Thus, by trying different models, the model that best fits the data set is determined (Vermunt \& Magidson, 2004). As a result, the BIC value is used to select the model that best fits the data (Lukočienè, Varriale, \& Vermunt, 2010). The latent class analysis in this current study was conducted using the Latent Gold 5.1 package program (Vermunt \& Magidson, 2013).

\section{RESULT / FINDINGS}

\subsection{Findings Related to the Validity and Reliability of the Attitude Scale}

In the scale, initially 11 items were written. The result of the Kaiser-Meyer-Olkin (KMO) test performed for the adequacy of the sample size consisting of 222 teachers before PCA was found to be .891. According to Çokluk et al. (2010), when this value is above .80, it can be interpreted as good. In addition, since Bartlett's sphericity test result $\left(x^{2}{ }_{(55)}=1004.785 ; p<.01\right)$ was less than .05 , it was understood that the data came from a multivariate normal distribution. As a result of the principal components analysis, the scree plot was examined, and it was observed that the items were collected in two components. The variance rate explained by these components was $59.956 \%$. Thus, when the component loads of the items were examined, it was seen that one item was overlapping. The factor loadings of this item were more than .32 in two factors and the difference between the values of the loading was less than .10. The overlapping item was removed from the scale, and 10 items remained in the scale. As a result of the principal component analysis for the remaining 10 items, it was seen that the scale was formed under two components. The scree plot is presented in Figure 1.

Figure 1. Scree plot for the scale with 10 items.

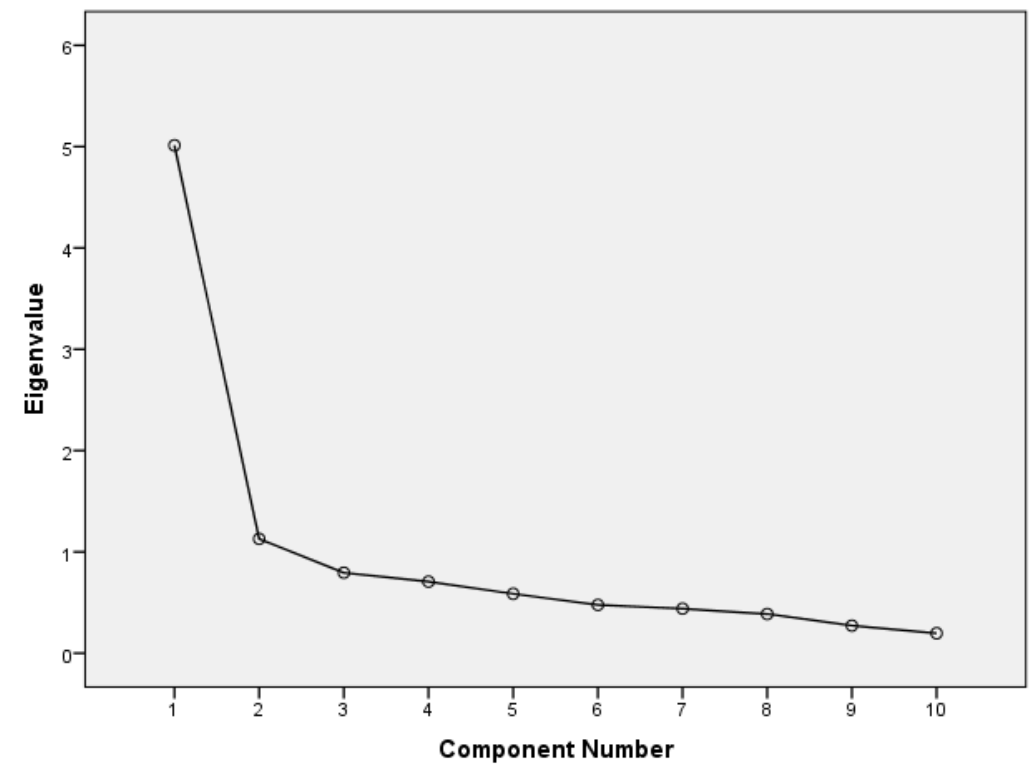


As seen in Figure 1, 10 items were collected under two components. The load values of items, total test correlation, and Cronbach's alpha values of the items under each component are presented in Table 1.

Table 1. Loads of items under the components, item total test correlation, and Cronbach's alpha values.

\begin{tabular}{|c|c|c|c|}
\hline \multirow[b]{2}{*}{ Items } & \multicolumn{2}{|c|}{$\begin{array}{l}\text { Loads of } \\
\text { components }\end{array}$} & \multirow{2}{*}{$\begin{array}{l}\text { Item total test } \\
\text { correlation }\end{array}$} \\
\hline & 1 & 2 & \\
\hline 1. I think workshops are unnecessary. & .891 & -.131 & $.698 * *$ \\
\hline $\begin{array}{l}\text { 2. It makes me stressed that the workshops will be opened in } \\
\text { my school. }\end{array}$ & .834 & -.032 & $.711 * *$ \\
\hline 3. I do not want to take part in workshops. & .795 & -.025 & $.711 * *$ \\
\hline 4. I do not like workshops at all. & .704 & .185 & $.778 * *$ \\
\hline 5. Workshops are an extra workload for us. & .625 & .053 & $.663 * *$ \\
\hline $\begin{array}{l}\text { 6. Instead of taking parts in the workshops, I prefer to teach in } \\
\text { the classroom. }\end{array}$ & .514 & .276 & $.733 * *$ \\
\hline $\begin{array}{l}\text { 7. I do not get bored because there is a continuous activity in } \\
\text { the workshops. }\end{array}$ & -.039 & .935 & $.746^{* *}$ \\
\hline 8. Opening workshops makes me happy. & -.063 & .875 & $.697 * *$ \\
\hline 9. I am interested in workshops. & .072 & .805 & $.740 * *$ \\
\hline 10. It makes me happy to take part in workshops. & .041 & .530 & $.545^{* *}$ \\
\hline The explained variance (\%) & 50.124 & 11.286 & $\begin{array}{r}\text { Tota } \\
61.410 \\
\end{array}$ \\
\hline Cronbach's alpha & .837 & .784 & .875 \\
\hline
\end{tabular}

As seen in Table 1, the first component consisted of six items, the loads belonging to this component were between .514 and .891, and the Cronbach's alpha coefficient for this component was .837. The second component consisted of four items, component loads varied between .530 and .935 , and the Cronbach's alpha coefficient was .784 . The variance explained for the entire scale was $61.410 \%$ and the Cronbach's alpha internal consistency coefficient was .875. It was shown in the results that the reliability coefficients of all sub-dimensions and all of scale were acceptable and reliable (Alpar, 2010). In addition, average variance extracted (AVE) and composite reliability $(\mathrm{CR})$ values were calculated within the scope of construct validity. AVE was calculated as 0.54 for the first factor and 0.64 for the second factor. Composite reliability was calculated as .87 for each factor. According to Hair, Black, Balin, and Anderson (2010), if the AVE is higher than .50 and CR is higher than .60, the validity of the construct should be considered as acceptable. In addition, as seen in Table 1, the total test scores of the items correlated with .663 to .778 for the first component and .545 to .746 for the second component. Correlation values must be .30 and above to express that the items adequately measure the desired property to be measured (Field, 2009). In this context, it can be stated that all items were particularly moderate and highly related, which was the intention of the measurement.

When the items in the first component were examined for naming the components, it was determined that there were items for teachers who had a negative attitude towards design and skill workshops. When the items in the second component were examined, it was seen that there were items for teachers who had a positive attitude towards design and skill workshops as well as wanted to work in these workshops. In order to determine the relationship among the two components in the scale, the correlation coefficients among the components were examined and it was seen that the correlation coefficient among the sub-components of the scale was .627 and 
was significant $(p<0.05)$. In general, it can be said that the correlations were at a medium level. When the average of both components was examined, the average of the first component was $\bar{x}=4.29(\mathrm{SD}=0.83)$, and the average of the second component was $\bar{x}=4.17(\mathrm{SD}=0.78)$. When the averages were analyzed based on subcomponents, both components seemed to have high component scores. While the first component expressed teachers' negative attitudes towards the workshops, the items in the second component showed their positive attitudes towards the workshops.

\subsection{Opinions of Teachers towards the Design and Skill Workshops}

The frequency, percentages, mean, and standard deviation of 30-items regarding teachers' opinions on design and skill workshops are presented in Table 2.

Table 2. Opinions of teachers towards the design and skill workshops.

\begin{tabular}{|c|c|c|c|}
\hline Items & $\begin{array}{l}\text { Strongly } \\
\text { Disagree }\end{array}$ & Disagree Undecided & Agree \\
\hline
\end{tabular}

\begin{tabular}{lcccccccccccc} 
& $\mathrm{f}$ & $\%$ & $\mathrm{f}$ & $\%$ & $\mathrm{f}$ & $\%$ & $\mathrm{f}$ & $\%$ & $\mathrm{f}$ & $\%$ & $\bar{x}$ & $\mathrm{ss}$ \\
\hline 1. Workshops improve students' self- & 1 & .5 & 1 & .5 & 2 & .9 & 72 & 32.4 & 145 & 65.3 & 4.62 & 0.58
\end{tabular} confidence.

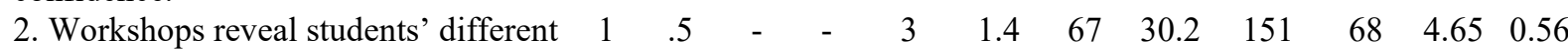
talents.

$\begin{array}{lllllllllllll}\text { 3. Through workshops, students acquire } & 1 & .5 & 1 & .5 & 12 & 5.4 & 89 & 40.1 & 117 & 52.7 & 4.45 & 0.66\end{array}$ the skills targeted to be taught in a

practical way.

$\begin{array}{lllllllllllll}\text { 4. Workshops increase the collaboration } & 1 & .5 & - & - & 7 & 3.2 & 75 & 33.8 & 139 & 62.6 & 4.58 & 0.60\end{array}$

among students.

$\begin{array}{lllllllllllll}\text { 5. Workshops develop students' critical } & 2 & .9 & 2 & .9 & 13 & 5.9 & 99 & 44.6 & 106 & 47.7 & 4.37 & 0.72\end{array}$

thinking skills.

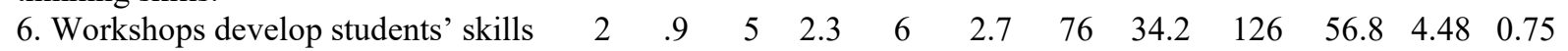

about working in groups.

7. Students are reluctant to participate in $\begin{array}{llllllllllll}72 & 32.4 & 95 & 42.8 & 32 & 14.4 & 12 & 5.4 & 8 & 3.6 & 2.04 & 1.01\end{array}$

workshops.

$\begin{array}{lllllllllllll}\text { 8. Workshops increase students' } & 1 & .5 & 8 & 3.6 & 28 & 12.6 & 106 & 47.7 & 79 & 35.6 & 4.14 & 0.81\end{array}$

commitment to school.

$\begin{array}{lllllllllllll}\text { 9. Workshops increase students' } & 1 & .5 & 4 & 1.8 & 34 & 15.3 & 111 & 50 & 68 & 30.6 & 4.11 & 0.76\end{array}$

academic success.

$\begin{array}{lllllllllllll}\text { 10. Workshops improve students' self- } & 2 & .9 & 2 & .9 & 6 & 2.7 & 110 & 49.5 & 101 & 45.5 & 4.38 & 0.68\end{array}$

expression skills.

$\begin{array}{lllllllllllll}\text { 11. Workshops are an essential key for } & - & - & 4 & 1.8 & 20 & 9 & 103 & 46.4 & 95 & 42.8 & 4.30 & 0.71\end{array}$

students to acquire the skills required for

this generation.

12. Workshops enable students to recognize professions.

13. Workshops increase students' motivation towards the lesson.

14. Workshops reinforce students'

entrepreneurial behavior.

15. Workshops increase students' leadership skills.

16. Workshops improve students' empathy building skills.

17. Workshops improve students' communication skills.

18. In workshops, it is difficult to protect students' health and ensure their safety.

$\begin{array}{cccccccccccc}1 & .5 & 3 & 1.4 & 14 & 6.3 & 101 & 45.5 & 103 & 46.4 & 4.36 & 0.70 \\ 2 & .9 & 4 & 1.8 & 19 & 8.6 & 113 & 50.9 & 83 & 37.4 & 4.23 & 0.75 \\ 1 & .5 & 2 & .9 & 13 & 5.9 & 108 & 48.6 & 98 & 44.1 & 4.35 & 0.67 \\ 1 & .5 & 5 & 2.3 & 24 & 10.8 & 101 & 45.5 & 89 & 40.1 & 4.24 & 0.77 \\ 1 & .5 & 5 & 2.3 & 30 & 13.5 & 110 & 49.5 & 75 & 33.8 & 4.14 & 0.77 \\ - & - & 3 & 1.4 & 6 & 2.7 & 119 & 53.6 & 93 & 41.9 & 4.37 & 0.61\end{array}$

$\begin{array}{llllllllllll}11 & 5 & 35 & 15.8 & 87 & 39.2 & 61 & 27.5 & 24 & 10.8 & 3.24 & 1.02\end{array}$ 
Table 2. Continued: Opinions of teachers towards the design and skill workshops.

19. The workshops provide practice of explained theoretical information.

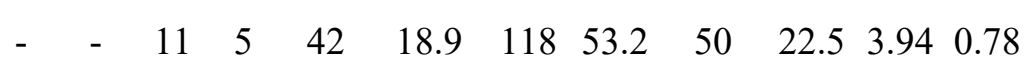

20. I find it difficult to direct the

students to the workshops according $\begin{array}{llllllllllll}38 & 17.1 & 91 & 41 & 56 & 25.2 & 29 & 13.1 & 5 & 2.3 & 2.42 & 1.00\end{array}$

to their interests.

21. I do not have the skills to teach students something in workshops.

$\begin{array}{lllll}49 & 22.1 & 82 & 36.9 & 58\end{array}$

$26.1 \quad 20 \quad 9 \quad 10$

$\begin{array}{lll}4.5 & 2.36 & 1.07\end{array}$

22. Workshops are not applicable to

the school where I work.

$\begin{array}{lllll}71 & 32 & 96 & 43.2 & 42\end{array}$

18.9

94.

4.13

$\begin{array}{lll}1.4 & 1.99 & 0.89\end{array}$

23. Each school will not have

enough workshops that students can 22

attend according to their interests.

24 . With the organization and

management of workshops, the

workload of school administrators

$\begin{array}{lllll}17 & 7.7 & 22 & 9.9 & 37\end{array}$

37.4

$\begin{array}{lll}67 & 30.2 & 16\end{array}$

$\begin{array}{lll}7.2 & 3.13 & 1.06\end{array}$

will increase.

25. For the workshops to be

implemented in all schools in Turkey $16 \quad 7.2 \quad 41 \quad 18.5 \quad 100$

is impossible.

26. The success of schools with

different workshops increases.

$\begin{array}{llllllllllll}3 & 1.4 & 4 & 1.8 & 44 & 19.8 & 106 & 47.7 & 63 & 28.4 & 4.01 & 0.83\end{array}$

27. Some parents do not want their

children to be in the workshops for

security reasons.

28. Students choose workshops not

according to their interests, but

\begin{tabular}{|c|c|c|c|c|c|c|c|c|c|c|}
\hline 22 & 9.9 & 47 & 21.2 & 65 & 29.3 & 67 & 30.2 & 21 & 9.5 & 3.08 \\
\hline 2 & .9 & 17 & 7.7 & 88 & 39.6 & 87 & 39.2 & 28 & 12.6 & 3.55 \\
\hline & 2.7 & 13 & 5.9 & 72 & 32.4 & 90 & 40.5 & 41 & 18.5 & 4.62 \\
\hline
\end{tabular}

according to parents' demands.

29. Parents want their children to

benefit from all workshops.

30. Parents want their children to go to schools with different workshops.

$\begin{array}{lllll}10 & 4.5 & 35 & 15.8 & 88\end{array}$

39.6

$67 \quad 30.2$

$\begin{array}{llll}21 & 9.5 & 3.24 & 0.98\end{array}$

When the questionnaire items in Table 2 are examined, the first 17 items include the opinions of teachers on the effect of the workshops on students. Items 18, 19, 20, and 21 are related to the teachers' own competences regarding the workshops. While, items 22, 23, 24, 25, and 26 are related to teachers' opinions on the effects of workshops on schools. The items 27, 28, 29, and 30 refer to teachers' opinions regarding the parents' responses to the workshops. When the responses provided for the 30 questionnaire items were evaluated, it was seen that the $2^{\text {nd }}, 1^{\text {st }}$, and $4^{\text {th }}$ items had the highest average. The item that teachers thought workshops had the most impact on students was the second item (Workshops reveal students' different talents). 98.2\% of the teachers responded to this item as "agree" and "strongly agree". The next item in which the teachers thought workshops had the most impact on students was the first item (Workshops improve students' self-confidence). $97.7 \%$ of the teachers responded to this item as "agree" and "strongly agree". The item in which teachers thought workshops had the least impact on students was the $7^{\text {th }}$ item (Students are reluctant to participate in workshops). $75.2 \%$ of the teachers expressed positive responses by providing a "strongly disagree" and "disagree" response to this negatively stated item. Then, the item in which teachers thought workshops had the least impact on students was the $9^{\text {th }}$ item (Workshops increase students' academic success). $80.6 \%$ of the teachers responded to this item as "agree" and "strongly agree". Although this rate was lower than other items, it was a high rate. Therefore, when the items in this category were analyzed in general, it can be stated that teachers thought that workshops would have positive effects on several student skills such as cooperation, communication, and leadership. 
When the items related to teachers' own competencies regarding workshops (items 18 to 21 and above) are examined, the item with the highest average $(\bar{x}=3.94)$ was the $19^{\text {th }}$ item (The workshops provide practices of the explained theoretical information). The item that teachers felt most inadequate about workshops was the $18^{\text {th }}$ item (In workshops, it is difficult to protect students' health and ensure their safety). Only $20.8 \%$ of the teachers stated that they could protect the health and safety of the students by responding to this negatively stated item by choosing "strongly disagree" and "disagree". When the teachers' views on the effects of the workshops on schools (between the item $22^{\text {nd }}$ and $26^{\text {th }}$ ), the $26^{\text {th }}$ item (The success of the schools with different workshops increases) had the highest average $(\bar{x}=4.01)$. Subsequently, the item with the highest average among other negatively stated items was item 24 (With the organization and management of workshops, the workload of school administrators will increase). In other words, $64.4 \%$ of teachers thought that workshops would increase their workload.

When the opinions of the teachers about the responses of the parents regarding the workshops are examined (items between 27 to 30), the item they think is the most positive was item 30 (Parents want their children to go to schools with different workshops). 59\% of the teachers responded to this item as "agree" and "strongly agree". That means, most teachers thought that the workshop would affect parents' school preferences. On the other hand, it was shown in item 28 that teachers' opinions regarding parents' responses to workshops as the least positive (Students choose workshops not according to their interests, but according to parents' demands). Only $39.7 \%$ of the teachers responded to this item as "agree" and "strongly agree". In other words, teachers thought that students would mostly choose workshops according to their interests.

\subsection{Profiles of Teachers Based on How They Rank Workshops in Terms of Their Importance}

As a result of the analysis made to determine the profiles of teachers according to their importance order regarding DSW, the results of compliance from the tested models are presented in Table 3.

Table 3. Teacher profiles according to the teachers' importance order regarding DSW.

\begin{tabular}{lcccccc}
\hline & & LL & BIC(LL) & Npar & L $^{2}$ & Class.Err. \\
\hline Model1 & 1-C & -5241.0445 & 11075.0882 & 111 & 8251.7659 & 0.0000 \\
Model2 & 2-C & -5160.0887 & 10977.2844 & 123 & 8089.8542 & 0.0681 \\
Model3 & 3-C & -5128.2635 & 10977.7421 & 135 & 8026.2038 & 0.1005 \\
Model4 & 4-C & -5092.6479 & 10970.6190 & 147 & 7954.9727 & 0.0956 \\
Model5 & 5-C & -5056.1109 & 10961.6529 & 159 & 7881.8986 & 0.0933 \\
\hline
\end{tabular}

Note $=$ C: Cluster

The statistics used to examine the compatibility of the data with the model regarding the ordering of the 11 workshops according the teachers' opinions of their importance as well as the different models attempted to determine the teacher profiles related to these rankings are presented in Table 3. As seen in Table 3, the classification error received the lowest value in a two-class model. The class with the lowest BIC value was the second model, that is, the two latent class models fit the data best. When the results of the two-class model were examined, $53.7 \%(f=115)$ of teachers were in cluster- 1 and $43.9 \%(f=94)$ in cluster- $2.67 .8 \%$ of the teachers in cluster- 1 were women and $30.4 \%$ were men. The average years of their seniority were 15.54 . $74.5 \%$ of the teachers in cluster- 2 were women and $23.4 \%$ were men. The average years of their seniority was 19.38 . According to the importance of the 11 workshops to be 
opened, it was seen that teachers were divided into two groups. The status of the workshops in the two clusters based on teachers' ranking is presented in Figure 2.

As shown in Figure 2, teachers' rankings of workshops including wood and metal (wood carving, wire bending, wood design, etc.), garden and animal care (agricultural production, planting, maintenance, landscaping, etc.), indoor sports (karate, gymnastics, dance, etc.) and life skills workshops (simple repairs, using small appliances, etc.) were close to each other in terms of their importance. Among these workshops, the teachers, in turn, considered life skills, garden and animal care, indoor sports, and wood and metal workshops as the most important ones.

Figure 2. Status of the workshops based on teachers' ranking.

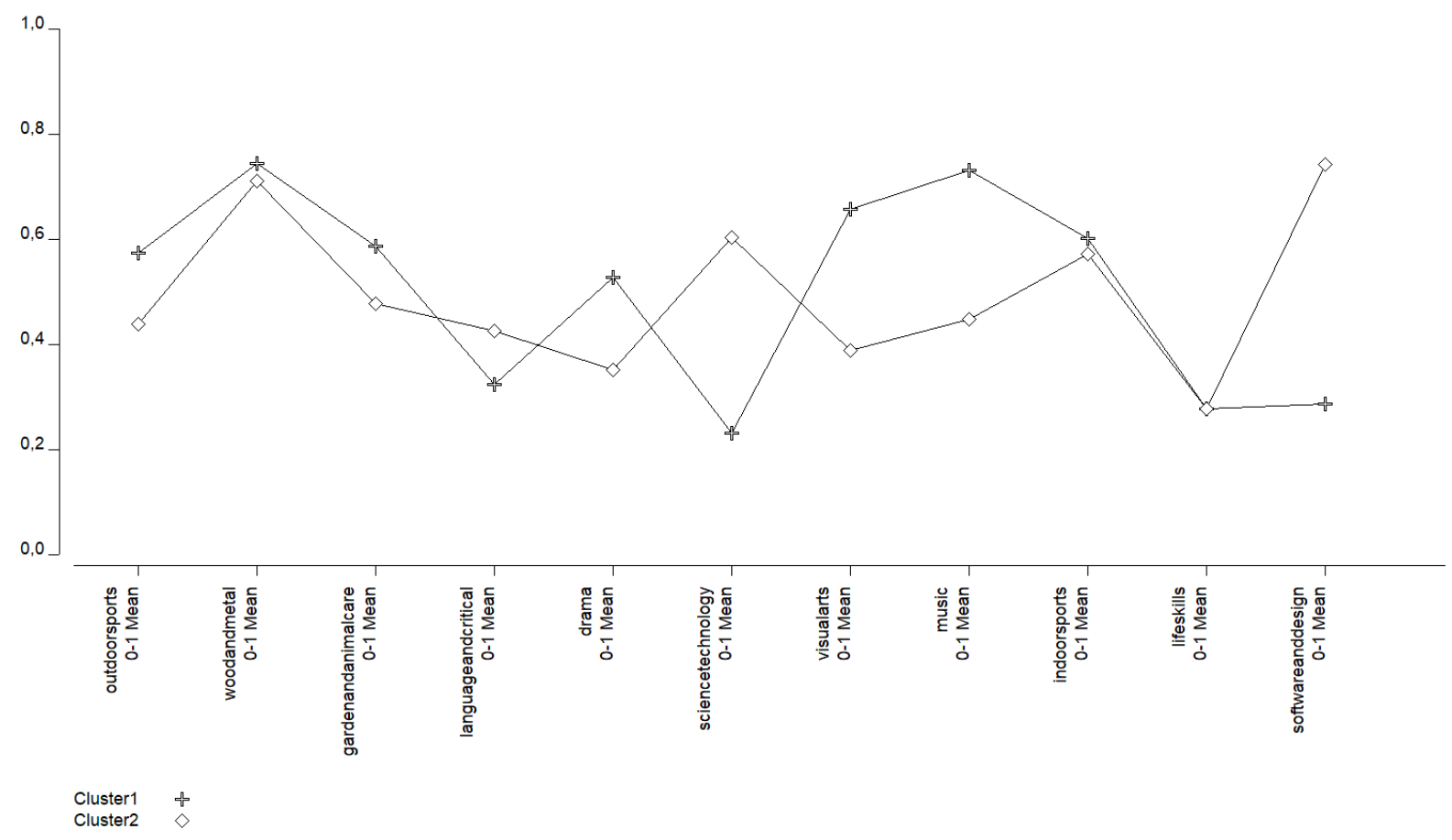

The workshops where the teachers were divided into two groups in terms of their importance were outdoor sports (football, basketball, tennis, etc.), language and critical thinking, drama (theater, diction, pantomime, etc.), science, technology, engineering and mathematics, visual arts (painting, sculpture, ceramics, etc.), music and software and design (robotics and coding, software, design, etc.) workshops. The importance ranking of the teachers in the first cluster of these workshops was as follows, starting from the most important: science, technology, engineering and mathematics; software and design; language and critical thinking; drama; outdoor sports; visual arts; and music. The order of importance of teachers in the second cluster was as follows, starting from the most important: drama; visual arts; language and critical thinking; music; outdoor sports; science, technology, engineering and mathematics; and software and design.

\section{DISCUSSION and CONCLUSION}

In this study, the aim was to determine the attitudes of teachers regarding design and skill workshops, which were carried out as pilot studies in several schools during 2019 according to the Educational Vision of 2023 as well as to develop a valid and reliable measurement tool aimed at measuring these attitudes. As a result of the analysis, a two-component scale with 10 items emerged. The two components that occurred in the scale were: i) teachers who have a negative attitude towards design and skill workshops, and ii) teachers who have a positive 
attitude towards design and skill workshops and want to take part in these workshops. While the reliability coefficients for the sub-dimensions of the scale and for the entire scale were good, the variance explained for the entire scale was sufficient. As a result, a valid and reliable measurement tool consisting of 10 items with two components was developed to determine teachers' attitudes towards design and skill workshops. Six items in the scale (items 1, 2, 3, 4, 5 and 6) were coded in reverse. According to the obtained results, it was determined that the general attitude of teachers was high.

Also, in this current study, the aim was to determine the opinions of teachers regarding the effects of design and skill workshops on students, teachers, parents, and school administrators. As a result of the research, it was determined that almost all teachers who participated in the study thought that the workshops would reveal students' unique abilities as well as help to develop the students' self-confidence. In addition, it was determined that they thought workshop participation would contribute to the development of several skills such as student communication, cooperation, and leadership. In parallel to this current study, another study aimed at determining the opinions of elementary school teachers regarding design-skill workshops (Gündoğan \& Can, 2020), finds that workshops positively affect students' development periods, self-perception, choice of profession, positive attitude towards school, and being active in their spare time.

As a result of this current research, it was determined that according to teachers' responses, protecting the health and safety of students and the organization and management of workshops were both difficult. In addition, the workload of school administrators would increase. Also, some teachers stated not having the skills to teach these workshops as well as they would have difficulty in placing students in workshops according to the students' interests. Furthermore, in line with the findings obtained in this current study, another study to determine the opinions of elementary school teachers regarding design and skill workshops, factors such as inadequate teachers, increased workload, parents seeing workshops as an extra expense, and limited physical infrastructure of schools are among the difficulties that can be experienced within the workshop process (Gündoğan \& Can, 2020). In order to eliminate these negative opinions regarding workshops, investigating teachers', students' and parents' opinions about their needs and interest can be helpful before designing and operating workshops in educational settings (Öztürk, 2020).

In this context, it is recommended that MoNE create opportunities for teachers to improve their knowledge and experience regarding the management, number, safety, and implementation of design and skill workshops. It is also recommended that MoNE determine the attitudes and opinions of teachers in this process by applying this developed scale and questionnaire. In addition, MoNE should also conduct interviews with teachers for gaining teacher insight regarding the elimination of workshop shortcomings if any appear prior to the pilot schools expanding in number.

Finally, in this current study, the aim was to determine the teachers' profiles according to the order of importance among the workshops to be opened. As a result, teachers were divided into two groups as those who thought science, technology, and software were more important, and teachers who thought drama and visual arts were more important. It was a remarkable finding that the opinions of teachers were extremely divergent from one another. Examination of the related literature showed that there was no study comparing the importance of design and skill workshops. However, it was seen that the opinions of teachers regarding the importance of different fields had been considered in past research. For example, in studies in which teachers' opinions regarding science, technology, and software related topics were obtained (Bakirc1 \& Kutlu, 2018; Göksoy \& Y1lmaz, 2018; Hsu et al., 2011), it was recognized that teachers consider these fields important since they contribute to the development of many $21^{\text {st }}$ century skills for 
students. For example, in a study in which teachers' opinions about robotics and coding course were obtained through interviews, Göksoy and Y1lmaz (2018) find that most teachers think robotics and coding lessons are very successful and beneficial in terms of developing students' analytical thinking skills, understanding the logic of algorithms, gaining coordination skills, and increasing their multi-faceted thinking skills. In addition, it is determined in Göksoy and Yilmaz (2018) that all of the teachers queried agreed upon the necessity of teaching robotics and coding lessons to students in all grade levels. While Hsu et al. (2011) conducted a survey investigation of 192 elementary school teachers' opinions and familiarity regarding the use of design, engineering, and technology within their classrooms. As a result, these teachers think that providing room for design, engineering, and technology lessons within their curriculum is important for students so that they can gain experiences and follow new developments in the age of science and technology. However, when it came to their familiarity with using technology in their classrooms, the teachers stated that they are not familiar and need in-service training to better prepare students for the future as well as not lose motivation within the classroom. Similarly, teachers in this current study also highlighted their concerns regarding how to manage workshops as well as having a lack of experience and knowledge regarding certain design and skill workshops they expected to be opened within their schools. Furthermore, in a study in which opinions of science teachers were obtained through interviews regarding the approach of science, technology, engineering and mathematics (STEM), Bakırc1 and Kutlu (2018) state that according to teachers, STEM will develop students' research, inquiry, and creativity skills; design products suitable for solving the determined problem situation; and increase their scientific process skills. The teachers also state that the STEM approach will increase the motivation and interest of students towards the lesson, allow students to create products, and increase laboratory use in schools. In another study, Güler and Kandemir (2015), state that the use of drama method by teachers in their lessons positively affects both the academic success and social skills of students. In this context, it can be stated that the findings in this current study for teachers having two diverse ranking choices is consistent with the research in the field of education. However, since there was no study in the literature comparing the importance or the effects of workshops according to teachers' opinions, it is recommended that further studies be carried out to reveal how teachers views regarding workshops and interviews be conducted to better understand the reasoning behind teachers decisions as well as compare any diverse or similar findings. Also, it was revealed through the results of this current study that teachers were divided into two clusters. The examination of these clusters showed that teachers in cluster- 2 had more years of seniority and that a higher proportion of them were women. Considering that the teachers in the second cluster were composed of teachers who believed that drama and visual arts were more important, may be due to female teachers utilizing drama more frequently in their classrooms as a result of greater confidence about using it as part of their instruction. Therefore, it can be stated that female teachers may see workshops regarding drama and visual arts as more important. For example, Güler and Kandemir (2015) find that female teachers have higher self-efficacy in using the drama method than male teachers.

Thus, in this current study, teachers' opinions and attitudes were investigated regarding the workshops that were slated to be opened in their pilot schools. Importantly, it was believed that identifying the workshops not deemed as important by teachers, could be a useful guide for MoNE in the preparation process for future school workshops. At the same time, the number of workshops which teachers considered as important could also increase. Therefore, along with the teachers, the order of importance of workshops presented in schools can also be determined according to the opinions of other stakeholders such as the students, parents, and administrators. As a result, after considering these views, important decisions can be made regarding the future establishment, opening and management of design and skill workshops within Turkish schools. 


\section{Acknowledgments}

The first draft of the paper was presented at $\mathrm{VI}^{\text {th }}$ International Eurasian Educational Research Congress, Ankara, Turkey.

\section{Declaration of Conflicting Interests and Ethics}

The authors declare no conflict of interest. This research study complies with research publishing ethics. The scientific and legal responsibility for manuscripts published in IJATE belongs to the author(s).

\section{Authorship contribution statement}

Aysegül Bayraktar: Investigation, research design, literature review, data collection, and writing the manuscript. Seher Yalcin: Research design, literature review, methodology, data collection, data analysis, and writing the manuscript.

\section{ORCID}

\section{Aysegül Bayraktar (D) https://orcid.org/0000-0002-1700-8899 \\ Seher Yalcin (iD https://orcid.org/0000-0003-0177-6727}

\section{REFERENCES}

Allen, M., Witt, P. L., \& Wheeless, L. R. (2006). The role of teacher immediacy as a motivational factor in student learning: Using meta-analysis to test a causal model. Communication Education, 55(1), 21-31.

Alpar, R. (2010). Uygulamalı istatistik ve geçerlik, güvenirlik [Applied statistics and validity, reliability]. Detay Yayıncılık.

Bakırcı, H., \& Kutlu, E. (2018). Fen bilimleri öğretmenlerinin FeTeMM yaklaşımı hakkındaki görüşlerinin belirlenmesi [Determination of science teachers' views on the STEM approach]. Turkish Journal of Computer and Mathematics Education (TURCOMAT), 9(2), 367-389. https://doi.org/10.16949/turkbilmat.417939.

Büyüköztürk, Ş. (2013). Sosyal bilimler için veri analizi el kitabı [Handbook of data analysis for social sciences] (18. bask1). Pegem Akademi.

Çokluk, Ö., Şekercioğlu, G., \& Büyüköztürk, Ş. (2010). Sosyal bilimler için çok değişkenli istatistik: SPSS ve Lisrel uygulamalart [Multivariate statistics for social sciences: SPSS and Lisrel applications]. Pegem Akademi.

DeVellis, R. F. (2003). Scale development theory and applications (2nd ed.). SAGE Publication, Inc.

Erdoğdu, M. Y. (2006). Yaratıcılık ile öğretmen davranışları ve akademik başarı arasındaki ilişkiler [Relationships between creativity, teacher behaviours and academic success]. Electronic Journal of Social Sciences, 5(17), 95-106.

Field, A. (2009). Discovering statistics using SPSS (3rd ed.). Sage Publications Ltd.

Fishbein, M., \& Ajzen, I. (1975). Belief, attitude, intention, and behavior: An introduction to theory and research. Addison-Wesley.

Fraenkel, J. R., Wallen, N. E., \& Hyun, H. H. (2012). How to design and evaluate research in education (8th ed.). McGraw-Hill.

Göksoy, S., \& Y1lmaz, İ. (2018). Bilişim teknolojileri öğretmenleri ve öğrencilerinin robotik ve kodlama dersine ilişkin görüşleri [The opinions of information relations teachers and their students with regard to lessons of robots and decoding]. Journal of Düzce University Institute of Social Sciences, 8(1), 178-196.

Güler, M., \& Kandemir, Ş. (2015). Öğretmenlerin drama yöntemine yönelik görüşleri ve öz yeterlik düzeyleri [Teachers' opinions on drama method and self-efficacy levels]. Journal of Kirşehir Education Faculty, 16(1), 111-130. 
Gündoğan, A., \& Can, B. (2020). Sınıf öğretmenlerinin tasarım-beceri atölyeleri hakkındaki görüşleri [Pre-service teachers' views on design-skill ateliers]. Turkish StudiesEducational Sciences, 15(2), 851-876. https://dx.doi.org/10.29228/TurkishStudies.40357

Hair, J. F., Black, W. C., Balin, B. J., \& Anderson, R. E. (2010). Multivariate data analysis. Maxwell Macmillan International Editions.

Hovardaoğlu, S. (2000). Davranış bilimleri için istatistik [Statistics for behavioral sciences]. Hatipoğlu Yayınları.

Hsu, M., Purzer, S., \& Cardella, M. E. (2011). Elementary teachers' views about teaching design, engineering, and technology. Journal of Pre-College Engineering Education Research (J-PEER), 1(2), 31-39.

Kurt, M., \& Duran, E. (2019). 2023 eğitim vizyonuna ilişkin öğretmen görüşleri [Teachers' view about the 2023 education vision]. International Journal of New Approaches in Social Studies, 3(1), 90-106.

Lukočienè, O., Varriale, R., \& Vermunt, J. K. (2010). The simultaneous decision(s) about the number of lower and higher-level classes in multilevel latent class analysis. Sociological Methodology, 40(1), 247-283. https://doi.org/10.1111/j.1467-9531.2010.01231.x.

Ministry of National Education [Milli Eğitim Bakanlığı-MEB]. (2018). 2023 Eğitim Vizyonu. [Educational vision of 2023], Retrieved January 20, 2019, from http://2023vizyonu.meb. gov.tr/doc/2023 EGITIM_VIZYONU.pdf

Öztürk, Z. (2020). Tasarım ve beceri atölyelerine yönelik uygulamalar - Almanya örneği [Applications for design and skill laboratories - example of Germany]. Millî Eğitim Dergisi [Journal of National Education], 49(227), 141-158.

Öztütüncü, S. (2016). Disiplinlerarası atölye dersleri üzerine bir değerlendirme [An evaluation on interdisciplinary workshop courses]. Akdeniz Sanat [Mediterranean Art], 9(19), 15-28.

Sezer, Ş. (2018). Öğretmenlerin sınıf yönetimi tutumlarının öğrencilerin gelişimi üzerindeki etkileri: Fenomenolojik bir çözümleme [The effects of teachers' classroom management attitudes on students' development: A phenomenological analysis]. Hacettepe University Journal of Education, 33(2), 534-549. https://doi.org/10.16986/HUJE.2017031319.

Tabachnick, B. G., \& Fidell, L. S. (2001). Using multivariate statistics (4th ed.), Allyn and Bacon,.

Tavşancıl, E. (2010). Tutumların ölçülmesi ve SPSS ile veri analizi [Measuring attitudes and data analysis with SPSS]. Nobel Yayın Dağıtım.

Uyumaz, G., \& Çokluk, Ö. (2016). An investigation of item order and rating differences in likert-type scales in terms of psychometric properties and attitudes of respondents. Journal of Theoretical Educational Science, 9(3), 400-425.

Vermunt, J. K. \& Magidson, J. (2004). Latent class analysis. In M. S. Lewis-Beck, A. Bryman, and T. F. Liao (Eds.), The sage encyclopedia of social sciences research methods (pp. 549-553). Sage Publications.

Vermunt, J. K., \& Magidson, J. (2013). Latent GOLD 5.0 upgrade manual. Statistical Innovations.

Witt, P. L., Wheeless, L. R., \& Allen, M. (2004). A meta-analytical review of the relationship between teacher immediacy and student learning. Communication Monographs, 71(2), 184-207. 